\title{
Investigating the Relationship Between Workability and Water Absorption of Periwinkle Shell Ash Cement Concrete
}

\section{Eme Dennis Budu*, Ohwerhi Kelly Erhiferhi}

Department of Civil and Environmental Engineering, University of Port Harcourt, Port Harcourt, Nigeria

Email address:

dennis.eme@uniport.edu.ng (E. D. Budu),kellyohwerhi@gmail.com (O. K. Erhiferhi)

${ }^{*}$ Corresponding author

\section{To cite this article:}

Eme Dennis Budu, Ohwerhi Kelly Erhiferhi. Investigating the Relationship Between Workability and Water Absorption of Periwinkle Shell Ash Cement Concrete. International Journal of Transportation Engineering and Technology. Vol. 5, No. 2, 2019, pp. 30-42. doi: $10.11648 /$ j.ijtet.20190502.12

Received: July 2, 2019; Accepted: July 31, 2019; Published: August 14, 2019

\begin{abstract}
In this paper, a comprehensive study on the relationship between workability in form of slump and water absorption, a permeability and durability property, of cement concrete blended with periwinkle shell ash is presented. Periwinkle shell ash was obtained from the granulation process of calcined periwinkle shells at a calcination temperature of $800^{\circ} \mathrm{C}$. Concrete specimens were designed using the Scheffe's simplex lattice theory. Standard experimental procedures using the slump height method was adopted in the determination of workability of concrete specimens. The water absorption of hardened concrete specimens was also determined from standard experimental procedures. Regression models of different forms; power, linear, logarithmic, exponential and polynomial forms were developed to correlate both properties using results from trial mixes. These models were subjected to validation tests using results from control mixes through F-Statistics. The models were also subjected to $\mathrm{R}^{2}$ analysis for further adequacy tests. Results obtained from this study revealed that although the 0.5 power model proved adequate, little correlation exist between both responses as illustrated from low $\mathrm{R}^{2}$ values obtained for all the models developed. It was therefore recommended that in models' validations, adequacy tests be used in conjunction with verification test $\left(\mathrm{R}^{2}\right.$ test) to prove the usefulness of such models' and that the relationship between other PSA cement concrete properties be investigated.
\end{abstract}

Keywords: Workability, Water Absorption, Periwinkle Shell Ash, Scheffe's Simplex Lattice

\section{Introduction}

Concrete is a basic construction material that consist of basically three constituents; binder (cement), water and aggregates (fine and coarse aggregates) in the right proportion. Admixtures may also be introduced into the concrete mix, either as partial or whole replacement for fine or coarse aggregate or for cement, to modify some desirable properties of the concrete such as compressive strength, workability, durability etc.

The use of periwinkle shell ash because of its satisfactory silica content, has yielded wonderful results in the partial replacement of cement for concrete production over the years [1-3]. This periwinkle shell ash is obtained from the calcination process of periwinkle shells, agricultural waste proceeds from the harvest of periwinkles [4]. When this pozzolan is mixed with cement in the presence of water, pozzolanic reaction occur leading to new binding phases with binding properties formed.

The quality of concrete produced is a demonstration of the intrinsic concrete properties such as, compressive strength, workability and durability [5]. The workability of concrete is a concrete property that is often referred to as the ease with which a concrete can be transported, placed and consolidated without excessive bleeding or segregation [6] or the internal workdone required to overcome the frictional forces between concrete ingredients for full compaction [7]. The water absorption of concrete is another very important property of concrete. The water absorption goes a long way in determining the durability of concrete [8]. The water absorption being a permeability parameter, is used to describe the change in mass of concrete due to ingress of water. One of the most important properties of a good quality 
concrete is low permeability, especially one resistant to freezing and thawing [9].

There have been no established mathematical relationship between workability and water absorption of concrete specimen. The aim of this study was to mathematically evaluate the relationship between workability (in the form of slump) and water absorption of PSA cement concrete. The durability of PSA cement concrete could be inferred from the water absorption value determined from the mathematical models developed between slump height and water absorption. Once the workability of the fresh PSA cement concrete specimen is known, the durability of that concrete could be estimated. To achieve this aim, the Scheffe's simplex lattice theory was adopted for the experimental mix design and then, regression models of different forms were developed and subjected to Fishers and coefficient of determination analysis for adequacy and validation tests respectively.

\section{Materials and Methods}

\subsection{Materials}

The periwinkle shell ash (PSA) was obtained from waste periwinkle shells, which were sourced from a waste periwinkle shell assemblage located in Aluu, Port Harcourt. These periwinkle shells were subjected to calcination temperature of $800^{\circ} \mathrm{C}$, being the optimum calcination temperature of periwinkle shell [3]. These burnt periwinkle shells were allowed to cool freely in the furnace and finely crushed and sieved where the portion passing sieve No. $200(75 \mu \mathrm{m})$ was used for the purpose of experiments.

River sand was used as fine aggregate for the essence of experiment. The sand was sundried for 48 hours to eliminate any trace of moisture. Sand was filtered using sieve size $4.5 \mathrm{~mm}$ to remove dirt and other organic matter. The filtered sand was then subjected to sieve analysis and was classified appropriately.

Granite of maximum size $20 \mathrm{~mm}$ was sourced from a construction site in Port Harcourt and used for the purpose of experiments. The sourced granite was washed to remove dirt and other unwanted particles. The washed granite was sundried for 24 hours. The dried coarse aggregate was subjected to sieve analysis to show the gradation pattern and was classified appropriately.

The Dangote $3 X$ cement (R. 425, CB 4227) was used for this study. This cement met standard requirements [10]. The cement was sourced from a local shop in Port Harcourt, Rivers State.

Portable water free of dirt and organic matter with $\mathrm{pH}$ value of about 6.9 was used in mixing of concrete components.

\subsection{Methods}

\subsubsection{Characterization of PSA and Cement}

The chemical analysis of the cement and PSA was done in a chemical laboratory in Port Harcourt in order to determine the oxide contents of both substances. The PSA was then classified appropriately.

\subsubsection{Classification of Aggregates}

The sieve analysis test was used in determination of properties of aggregates used in this study before their classification using the Unified Soil Classification System, USCS. The properties considered were the gradation and fineness modulus as per the [11] and [12] respectively. The coefficient of curvature $\left(\mathrm{C}_{\mathrm{C}}\right)$ and coefficient of uniformity $\left(\mathrm{C}_{\mathrm{U}}\right)$ were obtained from the particle size distribution curve. The coefficients were calculated using Equation (1) and Equation (2).

$$
\begin{gathered}
\mathrm{C}_{\mathrm{U}}=\frac{D_{60}}{D_{10}} \\
\mathrm{C}_{\mathrm{C}}=\frac{D_{30}^{2}}{D_{60} X D_{10}}
\end{gathered}
$$

Where:

$\mathrm{D}_{60}=$ particle size corresponding to $60 \%$ finer particles

$\mathrm{D}_{30}=$ particle size corresponding to $30 \%$ finer particles

$\mathrm{D}_{10}=$ particle size corresponding to $10 \%$ finer particles

A soil is considered well graded when these conditions are met: $4<\mathrm{C}_{\mathrm{U}}<6$ and $1<\mathrm{C}_{\mathrm{C}}<3$, otherwise, it is considered a uniformly graded soil.

\subsubsection{Development of Experimental Design Matrix}

The Scheffe's $(5,2)$ simplex lattice theory was used in the development of the design matrix used for experimental procedures, where 5 represents the number of PSA cement concrete components and 2 represents the maximum number of material interaction. The materials used are; water, periwinkle shell ash, cement, sand and granite. The following laws must be obeyed in a simplex lattice structure [13];

1. $X \neq$ negative; ( a pseudo mix ratio cannot be negative)

2. $0 \leq \mathrm{X}_{\mathrm{i}} \leq 1$; ( the pseudo mix ratio at position i must be between 0 and 1$)$

3. $\Sigma \mathrm{X}_{\mathrm{i}}=1$; ( summation of all pseudo mix ratios must be equal to 1$)$

Where, $\mathrm{X}_{\mathrm{i}}$ represents the pseudo component at the ith position of the lattice. Mix ratios are been represented in the pseudo mix form. For a $(\mathrm{q}, \mathrm{m})$ component mixture, the number of points is given by $C_{m}\left(q^{+} m^{-1)}\right.$ which produced 15 design points for a five components, 2 maximum interactions mixture (Scheffe [13]). Figure 1 represents the simplex lattice for a $(5,2)$ mixture.

The Scheffe's simplex lattice design requires that; $\Sigma \mathrm{X}=1$. This cannot be achieved with conventional mix ratio of the concrete mix. Hence, actual or real properties of the components must be converted to their pseudo (theoretical) components. The pseudo mix ratio is related to the actual mix ratio by; [13];

$$
\mathrm{Z}=[\mathrm{A}] \mathrm{X}
$$

Where:

$\mathrm{Z}=$ column matrix of real component ratio.

$\mathrm{X}=$ column matrix of pseudo component ratio.

[A] = coefficient matrix which is the transpose of the permutation matrix. 


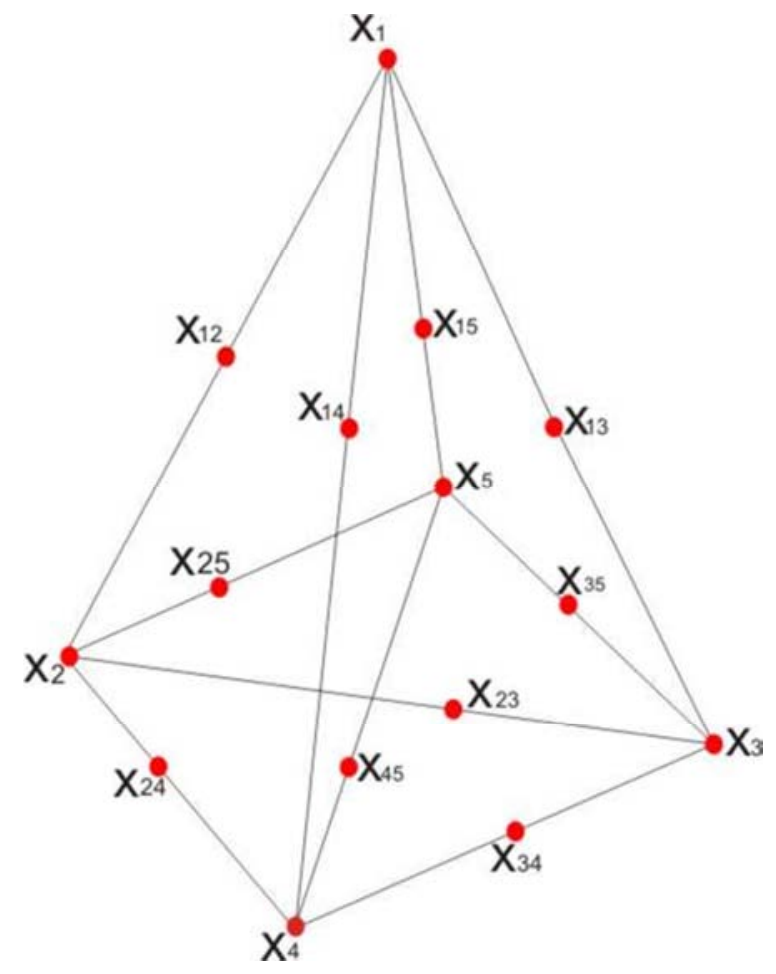

Figure 1. (5, 2) simplex lattice structure.

The permutation matrix was established from experience and intelligent guesses of concrete mixes. The water cement ratio was varied between $0.4-0.6$. The periwinkle shell ash was varied between $5 \%-25 \%$ by weight of cement bringing cement content to $75 \%-95 \%$. The ratio of fine aggregate and coarse aggregate in the mix was varied between 1-2.5 and 25 respectively. For the vertices, where pure substances are assumed to exist, the mix ratios are given as; $(0.45,0.95$, $0.05,2,4),(0.5,0.90,0.10,1,2),(0.55,0.85,0.15,1.75,3.5)$, $(0.40,0.80,0.20,1.25,2.50)$ and $(0.60,0.75,0.25,2.5,5.00)$ for these points. In matrix form;

$$
[P]=\left\{\begin{array}{ccccc}
0.45 & 0.95 & 0.05 & 2 & 4 \\
0.50 & 0.90 & 0.10 & 1 & 2 \\
0.55 & 0.85 & 0.15 & 1.75 & 3.5 \\
0.40 & 0.80 & 0.20 & 1.25 & 2.50 \\
0.60 & 0.75 & 0.25 & 2.50 & 5.00
\end{array}\right\}
$$

With the corresponding pseudo mix ratio being;

$$
[X]=\left\{\begin{array}{lllll}
1 & 0 & 0 & 0 & 0 \\
0 & 1 & 0 & 0 & 0 \\
0 & 0 & 1 & 0 & 0 \\
0 & 0 & 0 & 1 & 0 \\
0 & 0 & 0 & 0 & 1
\end{array}\right\}
$$

The transpose of matrix $[\mathrm{P}]$, becomes;

$$
[A]=\left\{\begin{array}{lllll}
0.45 & 0.50 & 0.55 & 0.40 & 0.60 \\
0.95 & 0.90 & 0.85 & 0.80 & 0.75 \\
0.05 & 0.10 & 0.15 & 0.20 & 0.25 \\
2 & 1 & 1.75 & 1.25 & 2.50 \\
4 & 2 & 3.50 & 2.50 & 5.00
\end{array}\right\}
$$

With the interaction points; $\mathrm{X}_{12}\left[\begin{array}{lllll}0.5 & 0.5 & 0 & 0 & 0\end{array}\right], \mathrm{X}_{13}\left[\begin{array}{lll}0.5 & 0\end{array}\right.$ $\left.\begin{array}{lll}0.5 & 0 & 0\end{array}\right], \mathrm{X}_{14}\left[\begin{array}{lllll}0.5 & 0 & 0 & 0.5 & 0\end{array}\right], \mathrm{X}_{15}\left[\begin{array}{lllll}0.5 & 0 & 0 & 0 & 0.5\end{array}\right], \mathrm{X}_{23}\left[\begin{array}{llll}0 & 0.5 & 0.5\end{array}\right.$

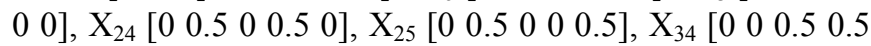
$0], X_{35}\left[\begin{array}{lllll}0 & 0 & 0.5 & 0 & 0.5\end{array}\right]$ and $X_{45}\left[\begin{array}{lllll}0 & 0 & 0 & 0.5 & 0.5\end{array}\right]$.

With the application of Equation (3), the mix ratios of the other positions were determined and presented in Table 1. Equation (3) was also applied in determining the actual mix ratios for the control mixes (Table 2) whose results were used

\begin{tabular}{|c|c|c|c|c|c|c|c|c|c|c|}
\hline \multirow{2}{*}{$\mathbf{N}$} & \multicolumn{5}{|c|}{ Pseudo Component } & \multicolumn{5}{|c|}{ Real component } \\
\hline & $\mathbf{X}_{1}$ & $\mathbf{X}_{2}$ & $\mathbf{X}_{3}$ & $\mathbf{X}_{4}$ & $\mathbf{X}_{5}$ & $Z_{1}$ & $\mathrm{Z}_{2}$ & $\mathbf{Z}_{3}$ & $\mathbf{Z}_{4}$ & $\mathbf{Z}_{5}$ \\
\hline 1 & 1 & 0 & 0 & 0 & 0 & 0.45 & 0.95 & 0.05 & 2 & 4 \\
\hline 2 & 0 & 1 & 0 & 0 & 0 & 0.50 & 0.90 & 0.10 & 1 & 2 \\
\hline 3 & 0 & 0 & 1 & 0 & 0 & 0.55 & 0.85 & 0.15 & 1.75 & 3.50 \\
\hline 4 & 0 & 0 & 0 & 1 & 0 & 0.40 & 0.80 & 0.20 & 1.25 & 2.50 \\
\hline 5 & 0 & 0 & 0 & 0 & 1 & 0.60 & 0.75 & 0.25 & 2.5 & 5.00 \\
\hline 6 & $1 / 2$ & $1 / 2$ & 0 & 0 & 0 & 0.475 & 0.925 & 0.075 & 1.50 & 3.00 \\
\hline 7 & $1 / 2$ & 0 & $1 / 2$ & 0 & 0 & 0.50 & 0.90 & 0.10 & 1.875 & 3.75 \\
\hline 8 & $1 / 2$ & 0 & 0 & $1 / 2$ & 0 & 0.425 & 0.875 & 0.125 & 1.625 & 3.25 \\
\hline 9 & $1 / 2$ & 0 & 0 & 0 & $1 / 2$ & 0.525 & 0.85 & 0.15 & 2.25 & 4.50 \\
\hline 10 & 0 & $1 / 2$ & $1 / 2$ & 0 & 0 & 0.525 & 0.875 & 0.125 & 1.375 & 2.75 \\
\hline 11 & 0 & $1 / 2$ & 0 & $1 / 2$ & 0 & 0.45 & 0.85 & 0.15 & 1.125 & 2.25 \\
\hline 12 & 0 & $1 / 2$ & 0 & 0 & $1 / 2$ & 0.55 & 0.825 & 0.175 & 1.75 & 3.50 \\
\hline 13 & 0 & 0 & $1 / 2$ & $1 / 2$ & 0 & 0.475 & 0.825 & 0.175 & 1.50 & 3.00 \\
\hline 14 & 0 & 0 & $1 / 2$ & 0 & $1 / 2$ & 0.575 & 0.80 & 0.20 & 2.125 & 4.25 \\
\hline 15 & 0 & 0 & 0 & $1 / 2$ & $1 / 2$ & 0.50 & 0.775 & 0.225 & 1.875 & 3.75 \\
\hline
\end{tabular}
for the validation of regression models developed in this study.

Table 1. Design Matrix for Trial Mixes.

\begin{tabular}{|c|c|c|c|c|c|c|c|c|c|c|}
\hline \multirow{2}{*}{$\mathbf{N}$} & \multicolumn{5}{|c|}{ Pseudo Component } & \multicolumn{5}{|c|}{ Real component } \\
\hline & $X_{1}$ & $\mathbf{X}_{2}$ & $\mathbf{X}_{3}$ & $\mathbf{X}_{4}$ & $\mathbf{X}_{5}$ & $Z_{1}$ & $\mathbf{Z}_{2}$ & $\mathbf{Z}_{3}$ & $\mathbf{Z}_{4}$ & $\mathbf{Z}_{5}$ \\
\hline 1 & $1 / 3$ & $1 / 3$ & $1 / 3$ & 0 & 0 & 0.50 & 0.90 & 0.10 & 1.5833 & 3.1667 \\
\hline 2 & $1 / 3$ & $1 / 3$ & 0 & $1 / 3$ & 0 & 0.45 & 0.8833 & 0.1167 & 1.4167 & 2.8333 \\
\hline
\end{tabular}

Table 2. Design Matrix for Control Mixes. 


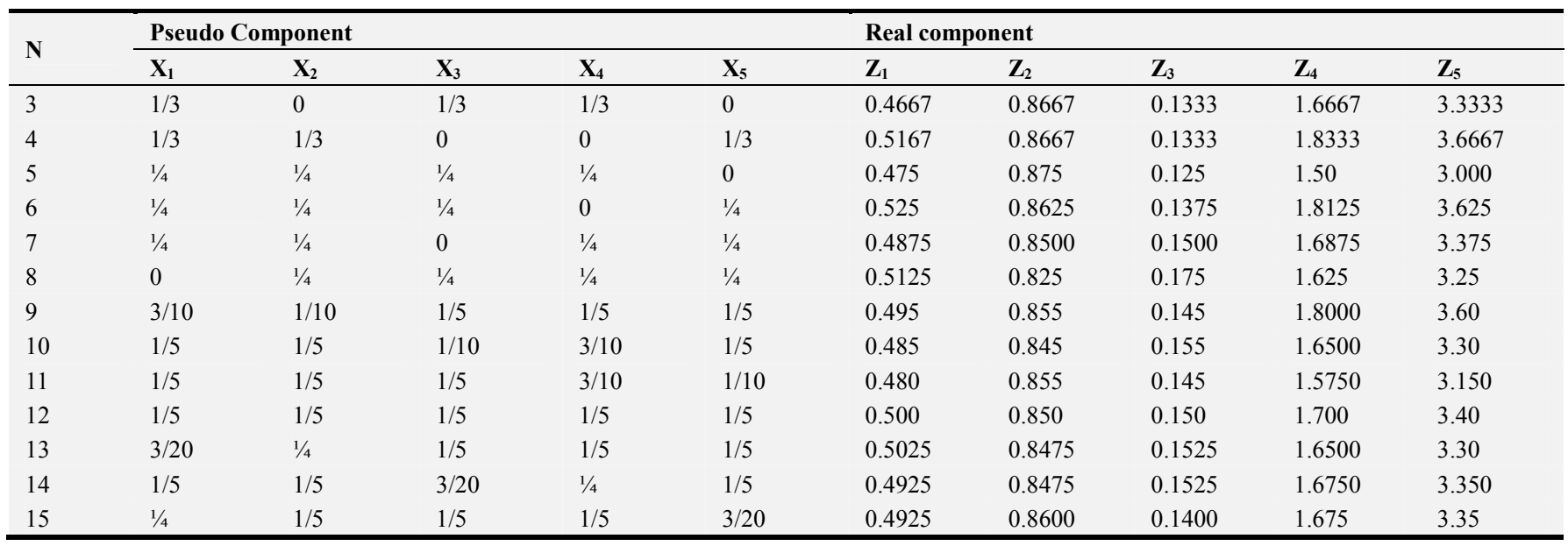

\subsubsection{Experimental Procedures}

The slump test was adopted here as the measure of the workability of fresh concrete and was in accordance to [14]. To carry out the experiment, these apparatus were used; slump cone (model HM-40, Gilson Company, USA), levelling surface, compaction rod, trowel and a metallic ruler. Fresh concrete specimen was poured on the slump cone placed on a level surface. The fresh concrete was compacted in three layers with the aid of compaction rod giving it 35 blows per layer uniformly across the entire face. The concrete specimen was then allowed to stand for 2 minutes after which, the cone was lifted off the unsupported concrete pile. The height difference between the cone and the slumped fresh concrete was measured with the metallic ruler and recorded as the slump height.

The water absorption of PSA cement concrete was determined in accordance to ASTM D3171 [15]. Cube specimens $(150 \mathrm{~mm}$ size) of concrete were moulded and allowed for 5 days to ensure moisture free samples. These samples after drying were weighed and again immersed in water for 24 hours. The wet weights were also measured and recorded. The water absorption was computed according to Equation (7) [15].

$$
W_{\mathrm{a}}=\frac{W \omega-W d}{W d} \chi 100
$$

Where; $\mathrm{W}_{\mathrm{a}}=$ water absorption; $w_{\omega}=$ wet weight of sample; $w_{d}=$ dry weight of sample.

\subsubsection{Models' Development and Validation}

Regression models' in linear, logarithmic, polynomial, exponential and power forms were used in relating the workability and water absorption of PSA cement concrete. Equations (8) to (13) were used in relating both responses.

Linear regression model:

$$
\mathrm{Y}=\mathrm{Ax}+\mathrm{B}
$$

Second degree Polynomial model:

$$
\mathrm{Y}=\mathrm{Ax}^{2}+\mathrm{Bx}+\mathrm{C}
$$

Logarithmic model:

$$
\mathrm{Y}=\mathrm{A} \operatorname{In} x+\mathrm{B}
$$

Exponential model:

$$
\mathrm{Y}=\mathrm{Ae}^{\mathrm{BX}}
$$

General Power model:

$$
\mathrm{Y}=\mathrm{Ax} \mathrm{x}^{\mathrm{B}}
$$

0.5 - power model:

$$
\mathrm{Y}=\mathrm{Ax}^{0.5}
$$

Where; $\mathrm{A}, \mathrm{B}$ and $\mathrm{C}$ are regression constants and $\mathrm{Y}, \mathrm{X}$ represents response parameters; water absorption and workability respectively.

These models were validated using F- statistics. The Fstatistics is given as the ratio of variance between the predicted/model response value and that of experimental value. The following hypothesis were adopted in validation of models;

Null Hypothesis: $\mathrm{H}_{0}=$ there is no significant difference between the experimental and predicted responses.

Alternate Hypothesis: $\mathrm{H}_{1}=$ there is a significant difference between the experimental and predicted responses.

Mathematically, the F-test is represented by Equation (14).

$$
\mathrm{F}=\frac{S_{1}^{2}}{S_{2}^{2}}
$$

Where; $S_{1}^{2}=$ Larger of both variances

$S_{2}^{2}=$ Smaller of both variance

$\mathrm{S}^{2}$ is obtained from Equation (15)

$$
\mathrm{S}^{2}=\frac{1}{n-1}\left[\sum(Y-\bar{Y})^{2}\right]
$$

Where: $\bar{Y}=$ Average mean of response, $\mathrm{Y}$

$\mathrm{Y}=$ Means of response

These models were also subjected to $\mathrm{R}^{2}$ analysis for further adequacy test. The $\mathrm{R}^{2}$ values were calculated in accordance to Equation (16).

$$
\mathrm{R}^{2}=\frac{\Sigma(\text { yest }-\overline{\mathrm{y}})^{2}}{\Sigma(y-\overline{\mathrm{y}})^{2}}
$$

Where; yest $=$ model value, $\mathrm{y}=$ experimental value and $\bar{y}$ $=$ mean experimental value. 


\section{Results and Discussion}

\subsection{Characteristics of Materials Used in Study}

\subsubsection{Characteristics of PSA and Cement}

Table 3 presents the result for the chemical/oxide composition analysis of periwinkle shell ash (PSA) and cement used in this study.

Table 3. Oxide Composition Results of PSA and cement.

\begin{tabular}{llll}
\hline \multirow{2}{*}{ S/No. } & \multirow{2}{*}{ Roperty (Oxide) } & Value (\%) & Cement \\
\cline { 3 - 4 } & $\mathrm{CaO}$ & PSA & 53.69 \\
2 & $\mathrm{Al}_{2} \mathrm{O}_{3}$ & 38.85 & 4.96 \\
3 & $\mathrm{Fe}_{2} \mathrm{O}_{3}$ & 11.04 & 3.08 \\
4 & $\mathrm{MgO}$ & 5.3 & 1.06 \\
5 & $\mathrm{SiO}$ & 1.13 & 20.26 \\
6 & $\mathrm{Na}_{2} \mathrm{O}$ & 34.55 & 0.27 \\
7 & $\mathrm{~K}_{2} \mathrm{O}$ & 0.11 & 0.52 \\
8 & $\mathrm{SO}_{3}$ & 0.15 & 4.53 \\
9 & $\mathrm{TiO}_{2}$ & 1.22 & - \\
10 & $\mathrm{P}_{2} \mathrm{O}_{5}$ & 0.18 & - \\
& $\mathrm{Loss}$ on $\mathrm{Ignition}$ & - & 7.95 \\
\hline
\end{tabular}

The chemical analysis shows that PSA met the requirement of a pozzolan with respect to its silica oxide content according to the standard which stipulates a minimum value of $25 \%$ for a substance to have a cementitious property (BS EN 197-1 [16]). With a value of $6.89 \%$ for loss on ignition, PSA met the requirement which stipulates a value of not more than 10\% (ASTMC618 [17]). The sulphur trioxide $\left(\mathrm{SiO}_{3}\right)$ didn't meet the specification with a value of $1.22 \%$ according to the standard which stipulates a value between 45\% (ASTMC618 [17]). The combine acidic oxides of $\left(\mathrm{Al}_{2} \mathrm{O}_{3}+\mathrm{SiO}_{2}+\mathrm{Fe}_{2} \mathrm{O}_{3}\right)$ with a value of $50.89 \%$, met the requirements for a Class C pozzolan (ASTMC618 [17]).

For comparative study of PSA and cement (Dangote $3 \mathrm{X}$ ), there are considerable variations in the chemical constituents considered. The calcium oxide recorded a percentage difference of $27.64 \%$ between PSA and cement with cement having a higher calcium oxide content. The highest percentage difference of $73.07 \%$ was recorded for sulphur trioxide. PSA had higher percentages of iron, aluminum and silicon oxides with percentage differences of $41.89 \%$, $55.07 \%$ and $41.36 \%$ respectively.

\subsubsection{Characteristics of Aggregates}

Tables 4 and 5 gives the result of sand and granite used in this study. Table 4 revealed that the fine aggregate was a zone II sand according to [11]. The fineness modulus of the sand and granite were obtained as 2.694 and 4.384 which makes the aggregates good construction materials [12].

Table 4. Sieve Analysis Test Result of Sand.

\begin{tabular}{lllll}
\hline Sieve size (mm) & Weight retained (g) & Cumulative Weight retained (g) & $\begin{array}{l}\text { Cumulative Percentage Weight } \\
\text { retained (\%) }\end{array}$ & Percentage Weight passing (\%) \\
\hline 4.75 & - & - & - & 100 \\
2.36 & 67 & 67 & 6.7 & 93.3 \\
1.18 & 146 & 213 & 53.7 & 78.7 \\
0.60 & 324 & 537 & 89.0 & 46.3 \\
0.30 & 353 & 890 & 98.7 & 11.0 \\
0.15 & 97 & 987 & 98.9 \\
0.075 & 2 & 989 & 100 \\
Pan & 1 & 1000 & 269.4 \\
Total cumm. weigth retained $(4.75 \mathrm{~mm}-150 \mu \mathrm{m})$ & \\
\hline
\end{tabular}

Table 5. Sieve Analysis Test Result of Granite.

\begin{tabular}{lllll}
\hline Sieve size (mm) & Weight retained (g) & Cumulative Weight retained (g) & $\begin{array}{l}\text { Cumulative Percentage Weight } \\
\text { retained (\%) }\end{array}$ & Percentage Weight passing (\%) \\
\hline 25 & - & - & - & 51.56 \\
19 & 1289 & 1289 & 86.84 & 48.44 \\
13.2 & 882 & 2171 & 100 & 13.16 \\
4.75 & 329 & 2500 & 100 \\
2.36 & 0 & - & - \\
\hline
\end{tabular}




\begin{tabular}{lllll}
\hline Sieve size (mm) & Weight retained (g) & Cumulative Weight retained (g) & $\begin{array}{l}\text { Cumulative Percentage Weight } \\
\text { retained (\%) }\end{array}$ & Percentage Weight passing (\%) \\
\hline 1.18 & 0 & - & 100 & - \\
Pan & 0 & 100 & - \\
Total cumm. weigth retained (20mm-1.18mm) & 438.40 & \\
\multicolumn{2}{l}{ Fineness modulus } & $438.40 / 100=4.384$ & \\
\hline
\end{tabular}

Figures 2 and 3 represent the particle size distribution of the sand and granite used in this study respectively. The classification coefficients; $\mathrm{C}_{\mathrm{u}}$ and $\mathrm{C}_{\mathrm{c}}$ were obtained from the gradation curves as 2.965 and 0.882 and 1.821 and 1.122 for sand and granite respectively. The aggregates were thus classified as uniformly graded aggregates.

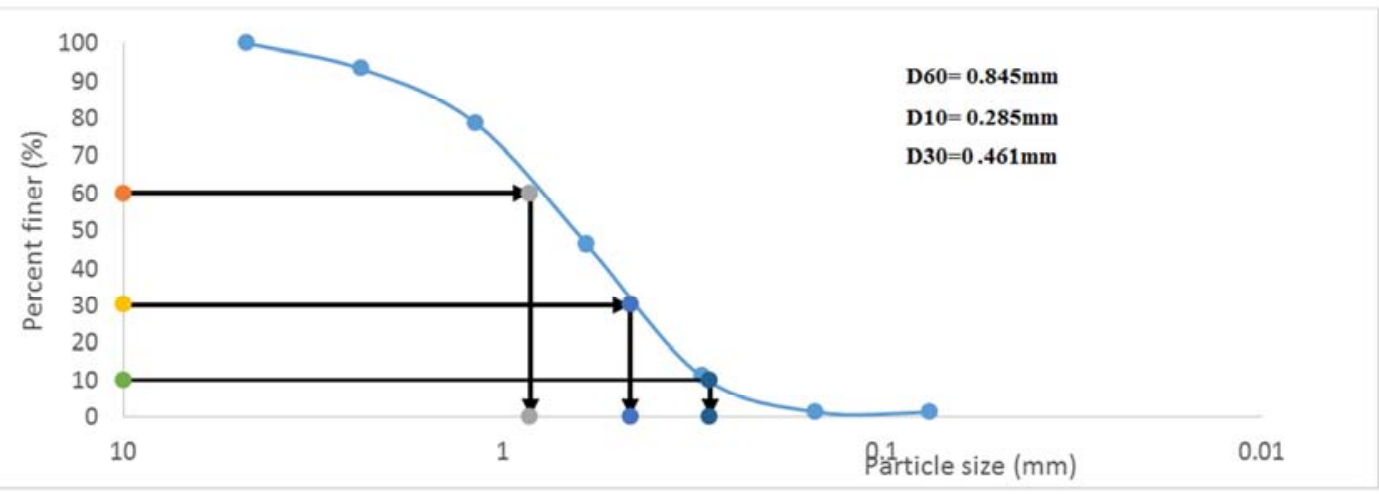

Figure 2. Particle Size Distribution of sand.

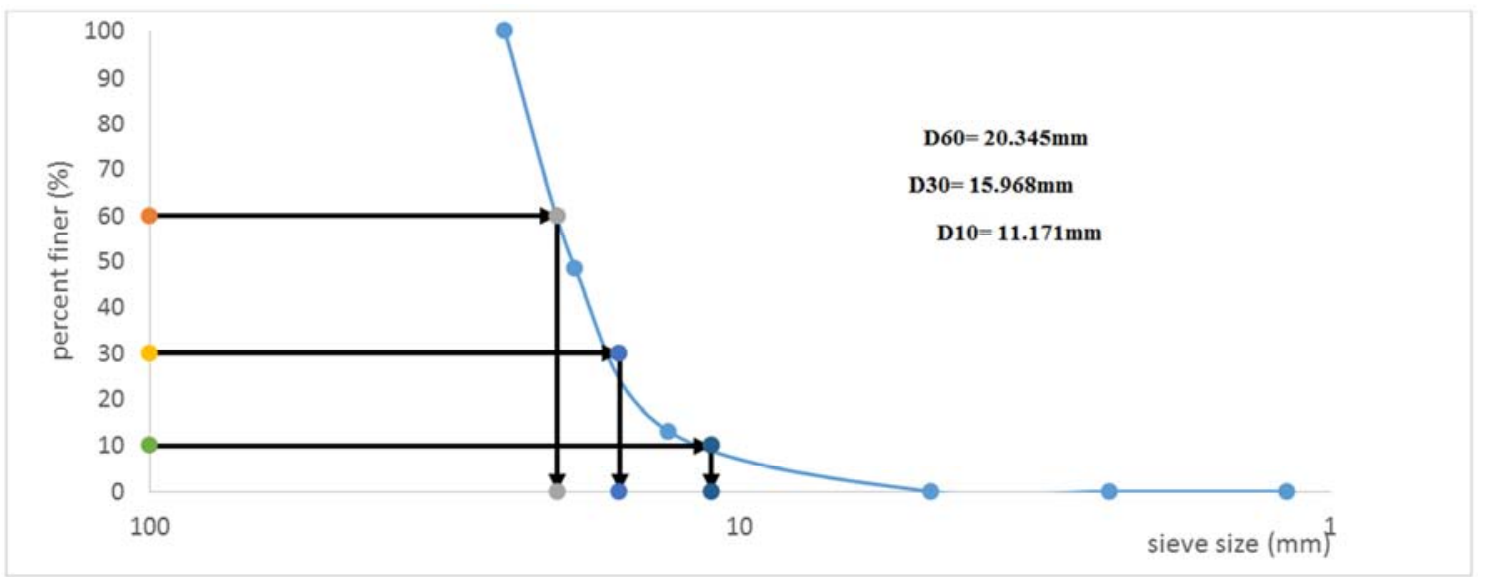

Figure 3. Particle Size Distribution of granite.

\subsection{Models' Development}

Table 6 gives the experimental results of responses obtained for trial mixes (Table 1) from which, all models were derived.

Table 6. Slump and Water Absorption test Result for Model Development.

\begin{tabular}{lllllllll}
\hline \multirow{2}{*}{ S/N } & \multicolumn{7}{l}{ Responses test result of PSA cement concrete } & \multicolumn{2}{l}{ Response W. } \\
\cline { 2 - 7 } & $\mathbf{Z}_{\mathbf{1}}$ & $\mathbf{Z}_{\mathbf{2}}$ & $\mathbf{Z}_{\mathbf{3}}$ & $\mathbf{Z}_{\mathbf{4}}$ & $\mathbf{Z}_{\mathbf{5}}$ & Response symbol & Response Slump (mm) & Absorption (\%) \\
\hline TP1 & 0.45 & 0.95 & 0.05 & 2 & 4 & $\mathrm{Y}_{1}$ & 20 & 2.89 \\
TP2 & 0.50 & 0.90 & 0.10 & 1 & 2 & $\mathrm{Y}_{2}$ & 100 & 3.86 \\
TP3 & 0.55 & 0.85 & 0.15 & 1.75 & 3.50 & $\mathrm{Y}_{3}$ & 110 & 2.57 \\
TP4 & 0.40 & 0.80 & 0.20 & 1.25 & 2.50 & $\mathrm{Y}_{4}$ & 60 & 2.59 \\
TP5 & 0.60 & 0.75 & 0.25 & 2.5 & 5.00 & $\mathrm{Y}_{5}$ & 85 & 3.88 \\
TP6 & 0.475 & 0.925 & 0.075 & 1.50 & 3.00 & $\mathrm{Y}_{12}$ & 70 & 2.19 \\
TP7 & 0.50 & 0.90 & 0.10 & 1.875 & 3.75 & $\mathrm{Y}_{13}$ & 80 & 2.30 \\
TP8 & 0.425 & 0.875 & 0.125 & 1.625 & 3.25 & $\mathrm{Y}_{14}$ & 100 & 2.56 \\
TP9 & 0.525 & 0.85 & 0.15 & 2.25 & 4.50 & $\mathrm{Y}_{15}$ & 90 & 3.69 \\
TP10 & 0.525 & 0.875 & 0.125 & 1.375 & 2.75 & $\mathrm{Y}_{23}$ & 130 & 3.37 \\
\hline
\end{tabular}




\begin{tabular}{lllllllll}
\hline \multirow{2}{*}{$\mathbf{S} / \mathbf{N}$} & \multicolumn{9}{l}{ Responses test result of PSA cement concrete } & \multicolumn{2}{c}{ Response W. } \\
& $\mathbf{Z}_{\mathbf{1}}$ & $\mathbf{Z}_{\mathbf{2}}$ & $\mathbf{Z}_{\mathbf{3}}$ & $\mathbf{Z}_{\mathbf{4}}$ & $\mathbf{Z}_{\mathbf{5}}$ & Response symbol & Response Slump (mm) & Absorption (\%) \\
\hline TP11 & 0.45 & 0.85 & 0.15 & 1.125 & 2.25 & $\mathrm{Y}_{24}$ & 80 & 2.58 \\
TP12 & 0.55 & 0.825 & 0.175 & 1.75 & 3.50 & $\mathrm{Y}_{25}$ & 120 & 2.61 \\
TP13 & 0.475 & 0.825 & 0.175 & 1.50 & 3.00 & $\mathrm{Y}_{34}$ & 130 & 2.22 \\
TP14 & 0.575 & 0.80 & 0.20 & 2.125 & 4.25 & $\mathrm{Y}_{35}$ & 80 & 2.47 \\
TP15 & 0.50 & 0.775 & 0.225 & 1.875 & 3.75 & $\mathrm{Y}_{45}$ & 95 & 2.35 \\
\hline
\end{tabular}

Figures 4 to 9 present the relationship between water absorption $(\%)$ and slump (mm) of PSA cement concrete for the different regression models considered. The independent variable, $\mathrm{x}$ is used to represent the slump while the dependent variable is represented by $y$.

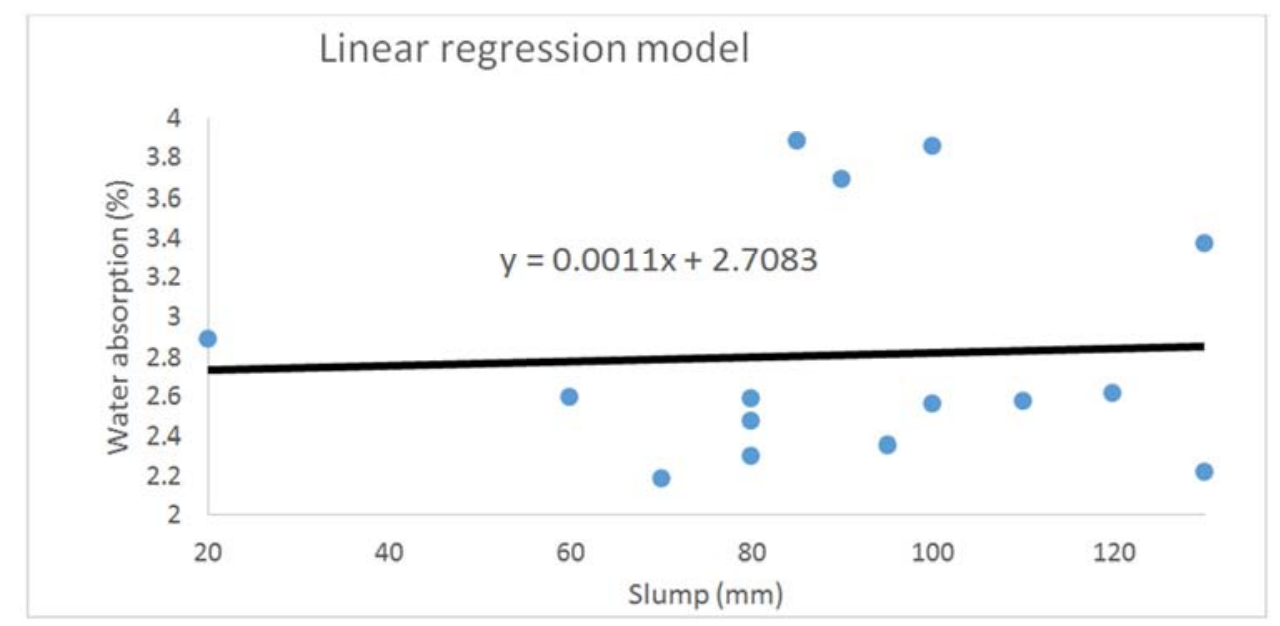

Figure 4. Linear relationship between responses.

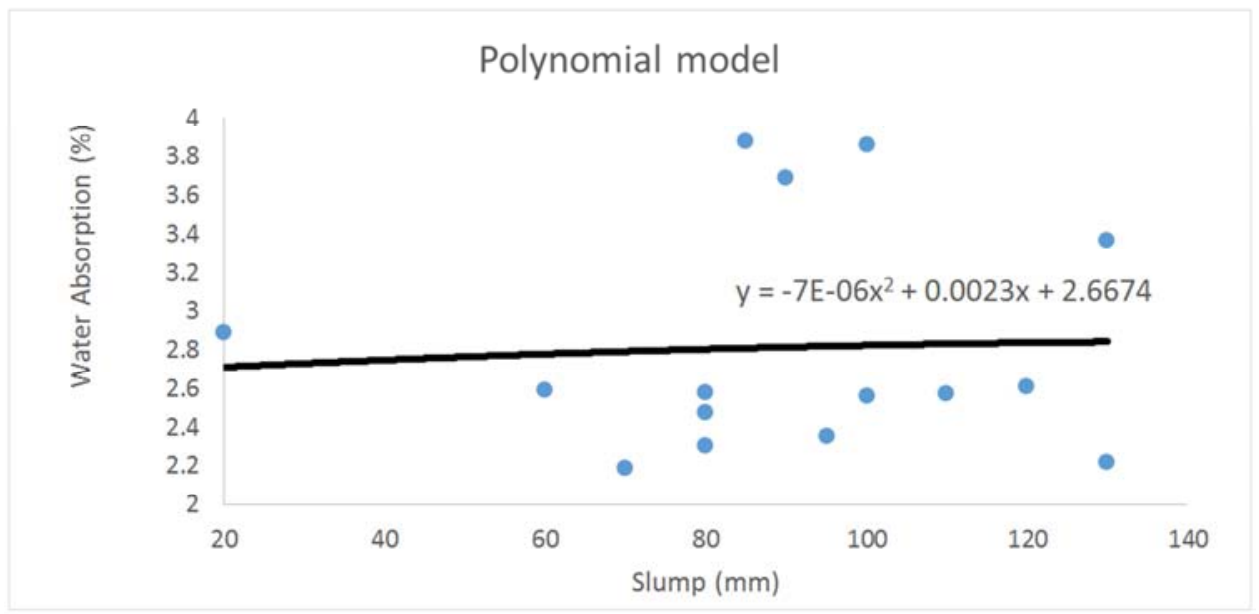

Figure 5. Polynomial relationship between responses.

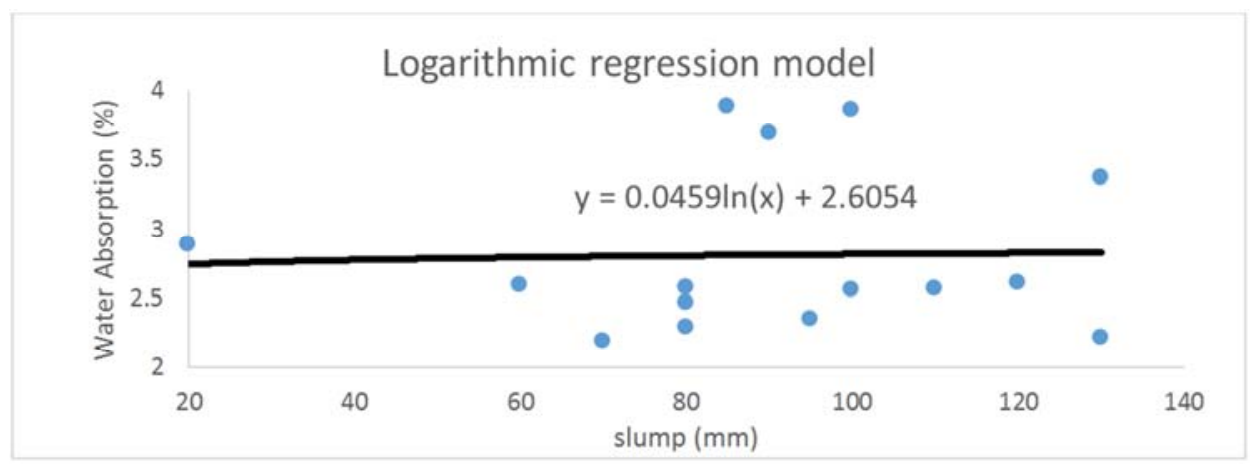

Figure 6. Logarithmic relationship between responses. 


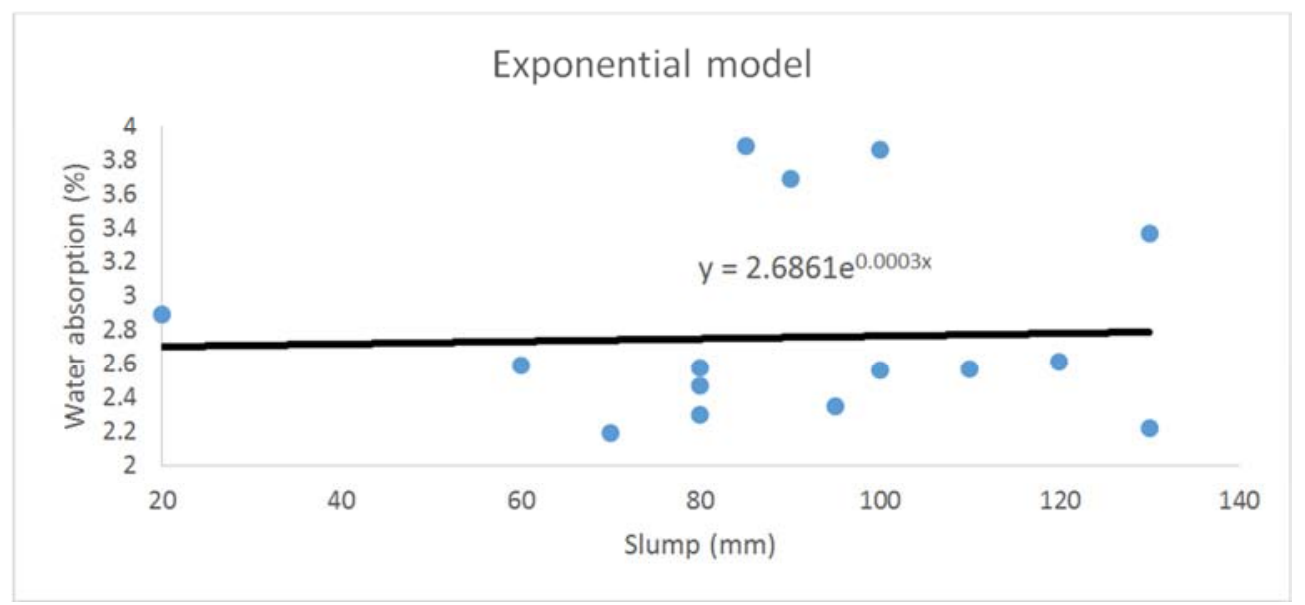

Figure 7. Exponential relationship between responses.

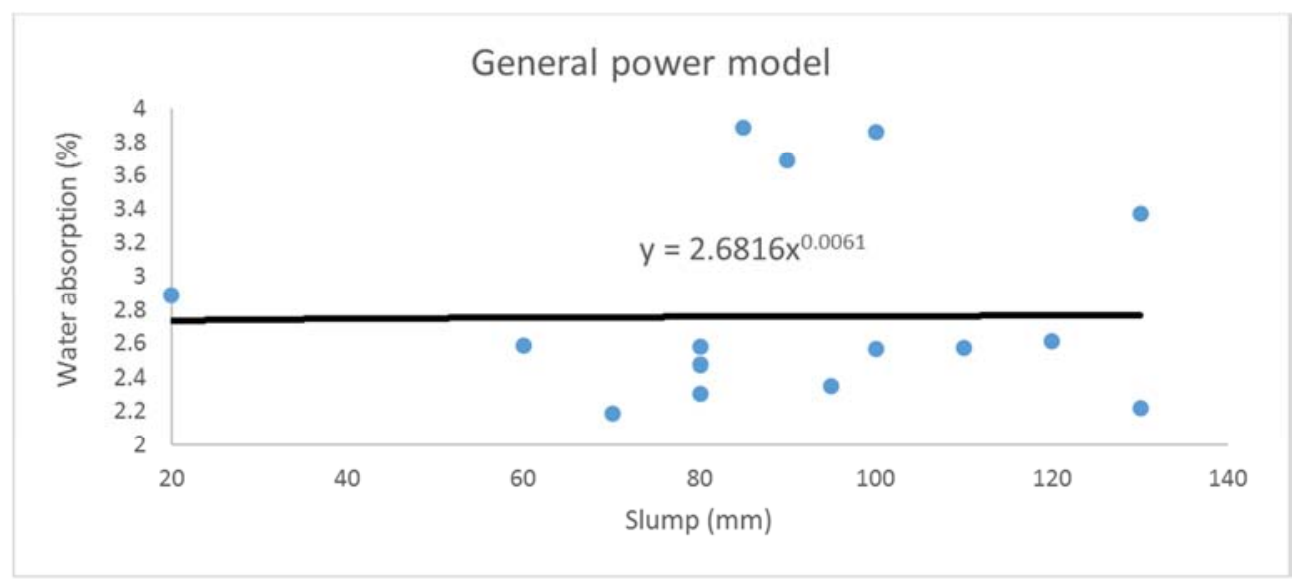

Figure 8. General power relationship between responses.

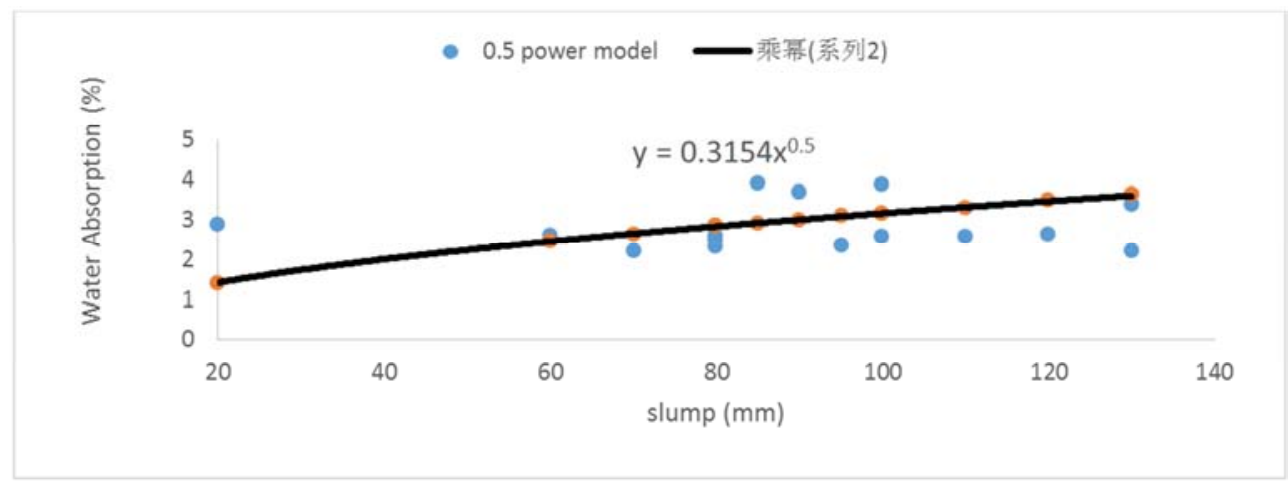

Figure 9. 0.5 power relationship between responses.

\subsection{Models' Adequacy and Validation Tests}

Table 7 presents the experimental results of the control mixes used for the validation of models developed in this study.

Table 7. Slump and Water absorption test Result for Models' Validation.

\begin{tabular}{llllllll}
\hline \multirow{2}{*}{$\mathbf{S} / \mathbf{N}$} & \multicolumn{7}{l}{ Slump Test Result for control points } \\
\cline { 2 - 7 } & $\mathbf{Z}_{\mathbf{1}}$ & $\mathbf{Z}_{\mathbf{2}}$ & $\mathbf{Z}_{\mathbf{3}}$ & $\mathbf{Z}_{\mathbf{4}}$ & $\mathbf{Z}_{\mathbf{5}}$ & Slump (mm) & Water Absorption (\%) \\
\hline CP1 & 0.50 & 0.90 & 0.10 & 1.5833 & 3.1667 & 95 & 2.53 \\
CP2 & 0.45 & 0.8833 & 0.1167 & 1.4167 & 2.8333 & 90 & 2.44 \\
CP3 & 0.4667 & 0.8667 & 0.1333 & 1.6667 & 3.3333 & 105 & 2.22 \\
CP4 & 0.5167 & 0.8667 & 0.1333 & 1.8333 & 3.6667 & 100 & 2.59 \\
CP5 & 0.475 & 0.875 & 0.125 & 1.50 & 3.000 & 110 & 2.42 \\
CP6 & 0.525 & 0.8625 & 0.1375 & 1.8125 & 3.625 & 90 & 2.55 \\
\hline
\end{tabular}




\begin{tabular}{llllllll}
\hline \multirow{2}{*}{$\mathbf{S} / \mathbf{N}$} & \multicolumn{9}{l}{ Slump Test Result for control points } & & & \\
\cline { 2 - 7 } & $\mathbf{Z}_{\mathbf{1}}$ & $\mathbf{Z}_{\mathbf{2}}$ & $\mathbf{Z}_{\mathbf{3}}$ & $\mathbf{Z}_{4}$ & $\mathbf{Z}_{5}$ & Slump (mm) & Water Absorption (\%) \\
\hline CP7 & 0.4875 & 0.8500 & 0.1500 & 1.6875 & 3.375 & 105 & 2.38 \\
CP8 & 0.5125 & 0.825 & 0.175 & 1.625 & 3.25 & 100 & 2.31 \\
CP9 & 0.495 & 0.855 & 0.145 & 1.8000 & 3.60 & 100 & 2.39 \\
CP10 & 0.485 & 0.845 & 0.155 & 1.6500 & 3.30 & 105 & 2.28 \\
CP11 & 0.480 & 0.855 & 0.145 & 1.5750 & 3.150 & 115 & 2.23 \\
CP12 & 0.500 & 0.850 & 0.150 & 1.700 & 3.40 & 95 & 2.36 \\
CP13 & 0.5025 & 0.8475 & 0.1525 & 1.6500 & 3.30 & 100 & 2.38 \\
CP14 & 0.4925 & 0.8475 & 0.1525 & 1.6750 & 3.350 & 105 & 2.3 \\
CP15 & 0.4925 & 0.8600 & 0.1400 & 1.675 & 3.35 & 100 & 2.32 \\
\hline
\end{tabular}

Tables 8 to 13 present the results of $\mathrm{F}$ - statistics conducted for the different regression models. Figures 10 to 15 present the results of the $\mathrm{R}^{2}$ analysis conducted in this study.

Table 8. F- Statistics for Linear Regression Model.

\begin{tabular}{|c|c|c|c|c|c|c|}
\hline $\mathbf{S} / \mathbf{N}$ & Experimental Value $=\mathbf{Y}_{\mathrm{e}}^{\mathrm{e}}$ & Model Value $=\mathbf{Y}^{\mathrm{m}_{\mathrm{m}}}$ & $\mathbf{Y}_{\mathrm{e}}-\hat{\mathbf{Y}}_{\mathrm{e}}$ & $\mathbf{Y}^{\mathrm{m}_{-}} \hat{\mathbf{Y}}^{\mathrm{m}}$ & $\left(\mathbf{Y}_{e}-\hat{\mathbf{Y}}_{e}\right)^{22}$ & $\left(\mathbf{Y}^{\mathrm{m}}-\hat{\mathbf{Y}}^{\mathrm{m}}\right)^{\mathbf{2}_{2}}$ \\
\hline $\mathrm{CP} 1$ & 2.53 & 2.81280 & 0.15000 & -0.00660 & 0.02250 & $4.356 \mathrm{E}-05$ \\
\hline $\mathrm{CP} 2$ & 2.44 & 2.80730 & 0.06000 & -0.01210 & 0.00360 & $1.464 \mathrm{E}-04$ \\
\hline $\mathrm{CP} 3$ & 2.22 & 2.82380 & -0.16000 & 0.00440 & 0.02560 & $1.936 \mathrm{E}-05$ \\
\hline CP4 & 2.59 & 2.81830 & 0.210 & -0.00110 & 0.04410 & $1.210 \mathrm{E}-06$ \\
\hline CP5 & 2.42 & 2.82930 & 0.040 & 0.00990 & 0.00160 & $9.801 \mathrm{E}-05$ \\
\hline CP6 & 2.55 & 2.80730 & 0.170 & -0.01210 & 0.02890 & $1.464 \mathrm{E}-04$ \\
\hline CP7 & 2.38 & 2.82380 & 0.000 & 0.00440 & 0.00000 & $1.936 \mathrm{E}-05$ \\
\hline CP8 & 2.31 & 2.81830 & -0.070 & -0.00110 & 0.00490 & $1.210 \mathrm{E}-06$ \\
\hline СР9 & 2.39 & 2.81830 & 0.010 & -0.00110 & 0.00010 & $1.210 \mathrm{E}-06$ \\
\hline CP10 & 2.28 & 2.82380 & -0.100 & 0.00440 & 0.01000 & $1.936 \mathrm{E}-05$ \\
\hline CP11 & 2.23 & 2.83480 & -0.150 & 0.01540 & 0.02250 & $2.372 \mathrm{E}-04$ \\
\hline CP12 & 2.36 & 2.81280 & -0.020 & -0.00660 & 0.00040 & $4.356 \mathrm{E}-05$ \\
\hline CP13 & 2.38 & 2.81830 & 0.000 & -0.00110 & 0.00000 & $1.210 \mathrm{E}-06$ \\
\hline CP14 & 2.3 & 2.82380 & -0.080 & 0.00440 & 0.00640 & $1.936 \mathrm{E}-05$ \\
\hline \multirow[t]{2}{*}{ CP15 } & 2.32 & 2.81830 & -0.060 & -0.00110 & 0.00360 & $1.210 \mathrm{E}-06$ \\
\hline & $\hat{\mathrm{Y}}_{\mathrm{e}}=2.380$ & $\hat{\mathrm{Y}}^{\mathrm{m}}=2.8194$ & & & $\sum=0.174$ & $\sum=7.986 \mathrm{E}-04$ \\
\hline
\end{tabular}

Table 9. F- Statistics for Second Degree Polynomial Regression Model.

\begin{tabular}{|c|c|c|c|c|c|c|}
\hline $\mathbf{S} / \mathbf{N}$ & Experimental Value $=Y_{e}^{e}$ & Model Value $=\mathbf{Y}^{\mathrm{m}_{\mathrm{m}}}$ & $\mathbf{Y}_{\mathrm{e}}-\hat{\mathbf{Y}}_{\mathrm{e}}$ & $\mathbf{Y}^{\mathrm{m}}-\hat{\mathbf{Y}}^{\mathrm{m}}$ & $\left(\mathbf{Y}_{e}-\hat{Y}_{e}\right)^{22}$ & $\left(\mathbf{Y}^{\mathrm{m}}-\hat{\mathbf{Y}}^{\mathrm{m}}\right)^{\mathbf{2 2}_{2}}$ \\
\hline $\mathrm{CP} 1$ & 2.53 & 2.82273 & 0.15000 & -0.00526 & 0.02250 & $2.767 \mathrm{E}-05$ \\
\hline $\mathrm{CP} 2$ & 2.44 & 2.81770 & 0.06000 & -0.01028 & 0.00360 & $1.058 \mathrm{E}-04$ \\
\hline $\mathrm{CP} 3$ & 2.22 & 2.83173 & -0.16000 & 0.00374 & 0.02560 & $1.399 \mathrm{E}-05$ \\
\hline CP4 & 2.59 & 2.82740 & 0.210 & -0.00058 & 0.04410 & $3.422 \mathrm{E}-07$ \\
\hline CP5 & 2.42 & 2.83570 & 0.040 & 0.00772 & 0.00160 & $5.952 \mathrm{E}-05$ \\
\hline CP6 & 2.55 & 2.81770 & 0.170 & -0.01028 & 0.02890 & $1.058 \mathrm{E}-04$ \\
\hline $\mathrm{CP} 7$ & 2.38 & 2.83173 & 0.000 & 0.00374 & 0.00000 & $1.399 \mathrm{E}-05$ \\
\hline CP9 & 2.39 & 2.82740 & 0.010 & -0.00058 & 0.00010 & $3.422 \mathrm{E}-07$ \\
\hline CP10 & 2.28 & 2.83173 & -0.100 & 0.00374 & 0.01000 & $1.399 \mathrm{E}-05$ \\
\hline CP11 & 2.23 & 2.83933 & -0.150 & 0.01134 & 0.02250 & $1.286 \mathrm{E}-04$ \\
\hline CP12 & 2.36 & 2.82273 & -0.020 & -0.00526 & 0.00040 & $2.767 \mathrm{E}-05$ \\
\hline CP13 & 2.38 & 2.82740 & 0.000 & -0.00058 & 0.00000 & $3.422 \mathrm{E}-07$ \\
\hline CP14 & 2.3 & 2.83173 & -0.080 & 0.00374 & 0.00640 & $1.399 \mathrm{E}-05$ \\
\hline CP15 & 2.32 & 2.82740 & -0.060 & -0.00058 & 0.00360 & $3.422 \mathrm{E}-07$ \\
\hline
\end{tabular}

Table 10. F- Statistics for Logarithmic Regression Model.

\begin{tabular}{|c|c|c|c|c|c|c|}
\hline $\mathbf{S} / \mathbf{N}$ & Experimental Value $=\mathbf{Y}_{\mathrm{e}}^{\mathrm{e}}$ & Model Value $=\mathbf{Y}^{\mathrm{m}_{\mathrm{m}}}$ & $\mathbf{Y}_{\mathrm{e}^{-}} \hat{\mathbf{Y}}_{\mathrm{e}}$ & $\mathbf{Y}^{\mathrm{m}}-\hat{\mathbf{Y}}^{\mathrm{m}}$ & $\left(\mathbf{Y}_{\mathrm{e}}-\hat{\mathbf{Y}}_{\mathrm{e}}\right)^{22}$ & $\left(\mathbf{Y}^{\mathrm{m}}-\hat{\mathbf{Y}}^{\mathrm{m}}\right)^{2_{2}}$ \\
\hline $\mathrm{CP} 1$ & 2.53 & 2.81442 & 0.15000 & -0.00271 & 0.02250 & $7.356 \mathrm{E}-06$ \\
\hline CP2 & 2.44 & 2.81194 & 0.06000 & -0.00519 & 0.00360 & $2.698 \mathrm{E}-05$ \\
\hline CP3 & 2.22 & 2.81902 & -0.16000 & 0.00188 & 0.02560 & $3.541 \mathrm{E}-06$ \\
\hline CP4 & 2.59 & 2.81678 & 0.210 & -0.00036 & 0.04410 & $1.280 \mathrm{E}-07$ \\
\hline CP5 & 2.42 & 2.82115 & 0.040 & 0.00402 & 0.00160 & $1.614 \mathrm{E}-05$ \\
\hline CP6 & 2.55 & 2.81194 & 0.170 & -0.00519 & 0.02890 & $2.698 \mathrm{E}-05$ \\
\hline CP7 & 2.38 & 2.81902 & 0.000 & 0.00188 & 0.00000 & $3.541 \mathrm{E}-06$ \\
\hline СР8 & 2.31 & 2.81678 & -0.070 & -0.00036 & 0.00490 & $1.280 \mathrm{E}-07$ \\
\hline СР9 & 2.39 & 2.81678 & 0.010 & -0.00036 & 0.00010 & $1.280 \mathrm{E}-07$ \\
\hline CP10 & 2.28 & 2.81902 & -0.100 & 0.00188 & 0.01000 & $3.541 \mathrm{E}-06$ \\
\hline
\end{tabular}




\begin{tabular}{|c|c|c|c|c|c|c|}
\hline $\mathbf{S} / \mathbf{N}$ & Experimental Value $=\mathbf{Y}_{\mathrm{e}}^{\mathrm{e}}$ & Model Value $=\mathbf{Y}^{\mathrm{m}_{\mathrm{m}}}$ & $\mathbf{Y}_{\mathrm{e}}-\hat{\mathbf{Y}}_{\mathrm{e}}$ & $\mathbf{Y}^{\mathrm{m}}-\hat{\mathbf{Y}}^{\mathrm{m}}$ & $\left(\mathbf{Y}_{\mathrm{e}^{-}}-\hat{\mathbf{Y}}_{\mathrm{e}}\right)^{2_{2}}$ & $\left(\mathbf{Y}^{\mathrm{m}}-\hat{\mathbf{Y}}^{\mathrm{m}}\right)^{\mathbf{2}_{2}}$ \\
\hline CP11 & 2.23 & 2.82319 & -0.150 & 0.00606 & 0.02250 & $3.669 \mathrm{E}-05$ \\
\hline CP12 & 2.36 & 2.81442 & -0.020 & -0.00271 & 0.00040 & $7.356 \mathrm{E}-06$ \\
\hline CP13 & 2.38 & 2.81678 & 0.000 & -0.00036 & 0.00000 & $1.280 \mathrm{E}-07$ \\
\hline CP14 & 2.3 & 2.81902 & -0.080 & 0.00188 & 0.00640 & $3.541 \mathrm{E}-06$ \\
\hline \multirow[t]{2}{*}{ CP15 } & 2.32 & 2.81678 & -0.060 & -0.00036 & 0.00360 & $1.280 \mathrm{E}-07$ \\
\hline & $\hat{\mathrm{Y}}_{\mathrm{e}}=2.380$ & $\hat{Y}^{\mathrm{m}}=2.8171$ & & & $\sum=0.174$ & $\sum=1.363 \mathrm{E}-04$ \\
\hline
\end{tabular}

Table 11. F-Statistics for Exponential Regression Model.

\begin{tabular}{|c|c|c|c|c|c|c|}
\hline $\mathbf{S} / \mathbf{N}$ & Experimental Value $=\mathbf{Y}_{\mathrm{e}}^{\mathrm{e}}$ & Model Value $=\mathbf{Y}^{\mathrm{m}_{\mathrm{m}}}$ & $\mathbf{Y}_{\mathrm{e}^{-}} \hat{\mathbf{Y}}_{\mathrm{e}}$ & $\mathbf{Y}^{m_{-}} \hat{\mathbf{Y}}^{\mathrm{m}}$ & $\left(\mathbf{Y}_{\mathrm{e}}-\hat{\mathbf{Y}}_{\mathrm{e}}\right)^{2_{2}}$ & $\left(\mathbf{Y}^{\mathrm{m}}-\hat{\mathbf{Y}}^{\mathrm{m}}\right)^{2_{2}}$ \\
\hline CP1 & 2.53 & 2.76376 & 0.15000 & -0.00498 & 0.02250 & $2.485 \mathrm{E}-05$ \\
\hline CP2 & 2.44 & 2.75961 & 0.06000 & -0.00913 & 0.00360 & $8.331 \mathrm{E}-05$ \\
\hline $\mathrm{CP} 3$ & 2.22 & 2.77206 & -0.16000 & 0.00332 & 0.02560 & $1.102 \mathrm{E}-05$ \\
\hline CP4 & 2.59 & 2.76790 & 0.210 & -0.00084 & 0.04410 & $6.989 \mathrm{E}-07$ \\
\hline CP5 & 2.42 & 2.77622 & 0.040 & 0.00748 & 0.00160 & $5.595 \mathrm{E}-05$ \\
\hline CP6 & 2.55 & 2.75961 & 0.170 & -0.00913 & 0.02890 & $8.331 \mathrm{E}-05$ \\
\hline CP7 & 2.38 & 2.77206 & 0.000 & 0.00332 & 0.00000 & $1.102 \mathrm{E}-05$ \\
\hline СР8 & 2.31 & 2.76790 & -0.070 & -0.00084 & 0.00490 & $6.989 \mathrm{E}-07$ \\
\hline СР9 & 2.39 & 2.76790 & 0.010 & -0.00084 & 0.00010 & $6.989 \mathrm{E}-07$ \\
\hline CP10 & 2.28 & 2.77206 & -0.100 & 0.00332 & 0.01000 & $1.102 \mathrm{E}-05$ \\
\hline CP11 & 2.23 & 2.78039 & -0.150 & 0.01165 & 0.02250 & $1.357 \mathrm{E}-04$ \\
\hline CP12 & 2.36 & 2.76376 & -0.020 & -0.00498 & 0.00040 & $2.485 \mathrm{E}-05$ \\
\hline CP13 & 2.38 & 2.76790 & 0.000 & -0.00084 & 0.00000 & $6.989 \mathrm{E}-07$ \\
\hline CP14 & 2.3 & 2.77206 & -0.080 & 0.00332 & 0.00640 & $1.102 \mathrm{E}-05$ \\
\hline \multirow[t]{2}{*}{ CP15 } & 2.32 & 2.76790 & -0.060 & -0.00084 & 0.00360 & $6.989 \mathrm{E}-07$ \\
\hline & $\hat{\mathrm{Y}}_{\mathrm{e}}=2.380$ & $\hat{Y}^{\mathrm{m}}=2.7687$ & & & $\sum=0.174$ & $\sum=4.555 \mathrm{E}-04$ \\
\hline
\end{tabular}

Table 12. F- Statistics for General Power Regression Model.

\begin{tabular}{|c|c|c|c|c|c|c|}
\hline $\mathbf{S} / \mathbf{N}$ & Experimental Value $=\mathrm{Y}_{\mathrm{e}}^{\mathrm{e}}$ & Model Value $=\mathbf{Y}^{\mathrm{m}_{\mathrm{m}}}$ & $\mathbf{Y}_{\mathrm{e}}-\hat{\mathbf{Y}}_{\mathrm{e}}$ & $\mathbf{Y}^{m_{-}} \hat{\mathbf{Y}}^{\mathrm{m}}$ & $\left(\mathbf{Y}_{\mathrm{e}}-\hat{\mathbf{Y}}_{\mathrm{e}}\right)^{22}$ & $\left(\mathbf{Y}^{\mathrm{m}}-\hat{\mathbf{Y}}^{\mathrm{m}}\right)^{2_{2}}$ \\
\hline $\mathrm{CP} 1$ & 2.53 & 2.75714 & 0.15000 & -0.00099 & 0.02250 & $9.884 \mathrm{E}-07$ \\
\hline $\mathrm{CP} 2$ & 2.44 & 2.75623 & 0.06000 & -0.00190 & 0.00360 & $3.623 \mathrm{E}-06$ \\
\hline $\mathrm{CP} 3$ & 2.22 & 2.75882 & -0.16000 & 0.00069 & 0.02560 & $4.755 \mathrm{E}-07$ \\
\hline CP4 & 2.59 & 2.75800 & 0.210 & -0.00013 & 0.04410 & $1.726 \mathrm{E}-08$ \\
\hline CP5 & 2.42 & 2.75960 & 0.040 & 0.00147 & 0.00160 & $2.168 \mathrm{E}-06$ \\
\hline CP6 & 2.55 & 2.75623 & 0.170 & -0.00190 & 0.02890 & $3.623 \mathrm{E}-06$ \\
\hline CP7 & 2.38 & 2.75882 & 0.000 & 0.00069 & 0.00000 & $4.755 \mathrm{E}-07$ \\
\hline CP8 & 2.31 & 2.75800 & -0.070 & -0.00013 & 0.00490 & $1.726 \mathrm{E}-08$ \\
\hline СР9 & 2.39 & 2.75800 & 0.010 & -0.00013 & 0.00010 & $1.726 \mathrm{E}-08$ \\
\hline CP10 & 2.28 & 2.75882 & -0.100 & 0.00069 & 0.01000 & 4.755E-07 \\
\hline CP11 & 2.23 & 2.76035 & -0.150 & 0.00222 & 0.02250 & $4.933 \mathrm{E}-06$ \\
\hline CP12 & 2.36 & 2.75714 & -0.020 & -0.00099 & 0.00040 & $9.884 \mathrm{E}-07$ \\
\hline CP13 & 2.38 & 2.75800 & 0.000 & -0.00013 & 0.00000 & $1.726 \mathrm{E}-08$ \\
\hline CP14 & 2.3 & 2.75882 & -0.080 & 0.00069 & 0.00640 & $4.755 \mathrm{E}-07$ \\
\hline \multirow[t]{2}{*}{ CP15 } & 2.32 & 2.75800 & -0.060 & -0.00013 & 0.00360 & $1.726 \mathrm{E}-08$ \\
\hline & $\hat{\mathrm{Y}}_{\mathrm{e}}=2.380$ & $\hat{\mathrm{Y}}^{\mathrm{m}}=2.7581$ & & & $\sum=0.174$ & $\sum=1.831 \mathrm{E}-05$ \\
\hline
\end{tabular}

Table 13. F-Statistics for 0.5 Power Regression Model.

\begin{tabular}{lllllll}
\hline $\mathbf{S} / \mathbf{N}$ & Experimental Value $=\mathbf{Y}_{\mathbf{e}}^{\mathbf{e}}$ & Model Value $=\mathbf{Y}^{\mathbf{m}_{\mathrm{m}}}$ & $\mathbf{Y}_{\mathrm{e}} \hat{\mathbf{Y}}_{\mathbf{e}}$ & $\mathbf{Y}^{\mathrm{m}}-\hat{\mathbf{Y}}^{\mathbf{m}}$ & $\left(\mathbf{Y}_{\mathrm{e}}-\hat{\mathbf{Y}}_{\mathbf{e}}\right)^{\mathbf{2}_{\mathbf{2}}}$ & $\left(\mathbf{Y}^{\mathrm{m}}-\hat{\mathbf{Y}}^{\mathrm{m}}\right)^{\mathbf{2}_{\mathbf{2}}}$ \\
\hline 1 & 2.53 & 3.07414 & 0.15000 & -0.09388 & 0.02250 & $8.814 \mathrm{E}-03$ \\
2 & 2.44 & 2.99215 & 0.06000 & -0.17588 & 0.00360 & $3.093 \mathrm{E}-02$ \\
3 & 2.22 & 3.23189 & -0.16000 & 0.06386 & 0.02560 & $4.079 \mathrm{E}-03$ \\
4 & 2.59 & 3.15400 & 0.210 & -0.01402 & 0.04410 & $1.967 \mathrm{E}-04$ \\
5 & 2.42 & 3.30794 & 0.040 & 0.13992 & 0.00160 & $1.958 \mathrm{E}-02$ \\
6 & 2.55 & 2.99215 & 0.170 & -0.17588 & 0.02890 & $3.093 \mathrm{E}-02$ \\
7 & 2.38 & 3.23189 & 0.000 & 0.06386 & 0.00000 & $4.079 \mathrm{E}-03$ \\
8 & 2.31 & 3.15400 & -0.070 & -0.01402 & 0.00490 & $1.967 \mathrm{E}-04$ \\
9 & 2.39 & 3.15400 & 0.010 & -0.01402 & 0.00010 & $1.967 \mathrm{E}-04$ \\
10 & 2.28 & 3.23189 & -0.100 & 0.06386 & 0.01000 & $4.079 \mathrm{E}-03$ \\
11 & 2.23 & 3.38229 & -0.150 & 0.21426 & 0.02250 & $4.591 \mathrm{E}-02$ \\
12 & 2.36 & 3.07414 & -0.020 & -0.09388 & 0.00040 & $8.814 \mathrm{E}-03$ \\
13 & 2.38 & 3.15400 & 0.000 & -0.01402 & 0.00000 & $1.967 \mathrm{E}-04$ \\
14 & 2.3 & 3.23189 & -0.080 & 0.06386 & 0.00640 & $4.079 \mathrm{E}-03$ \\
15 & 2.32 & 3.15400 & -0.060 & -0.01402 & 0.00360 & $1.967 \mathrm{E}-04$ \\
& $\mathbf{Y}_{\mathrm{Y}}=2.380$ & $\hat{\mathbf{Y}}^{\mathrm{m}=3.1680}$ & & & $\sum=0.174$ & $\sum=1.623 \mathrm{E}-01$ \\
\hline
\end{tabular}




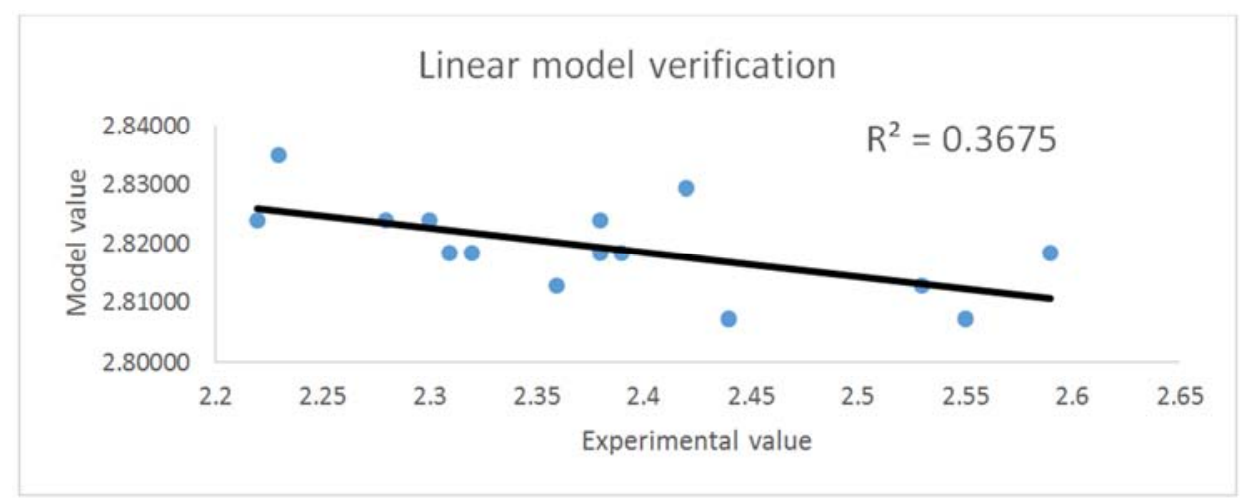

Figure 10. $R^{2}$ Analysis of Linear Model.

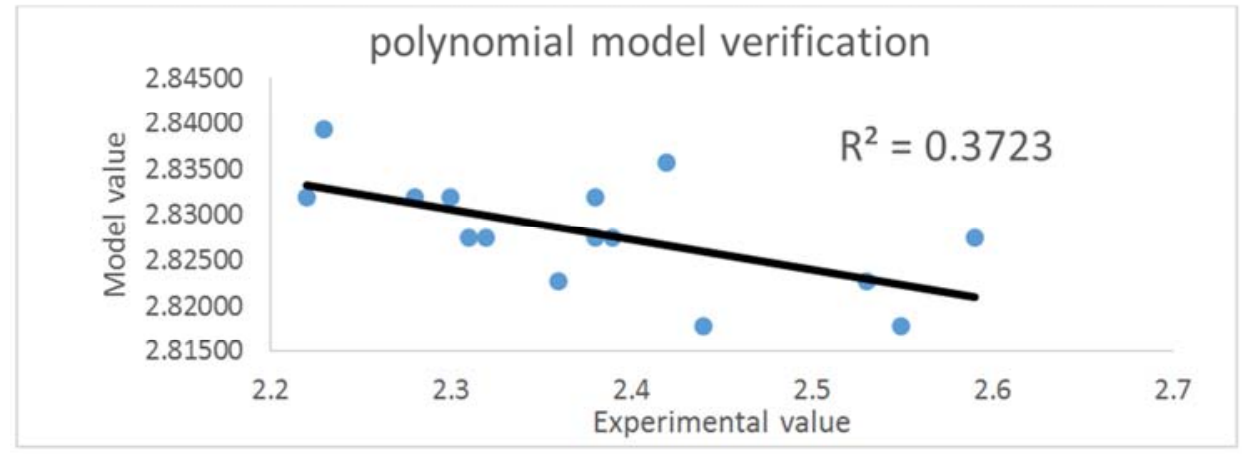

Figure 11. $R^{2}$ Analysis of Polynomial Model.

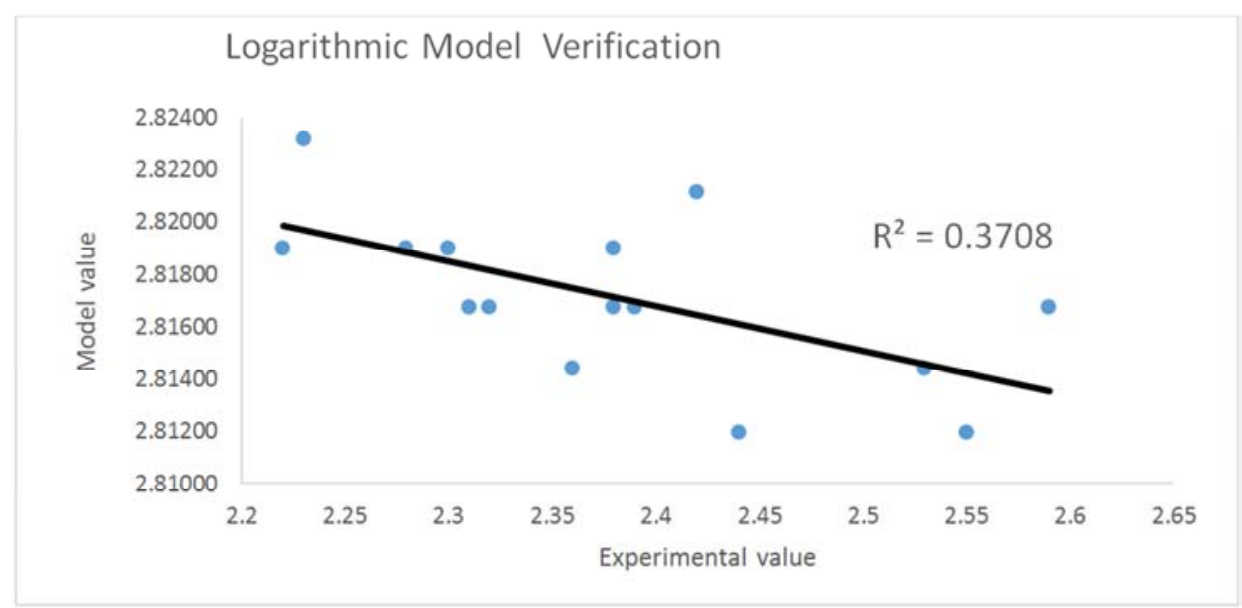

Figure 12. $R^{2}$ Analysis of Logarithmic Model.

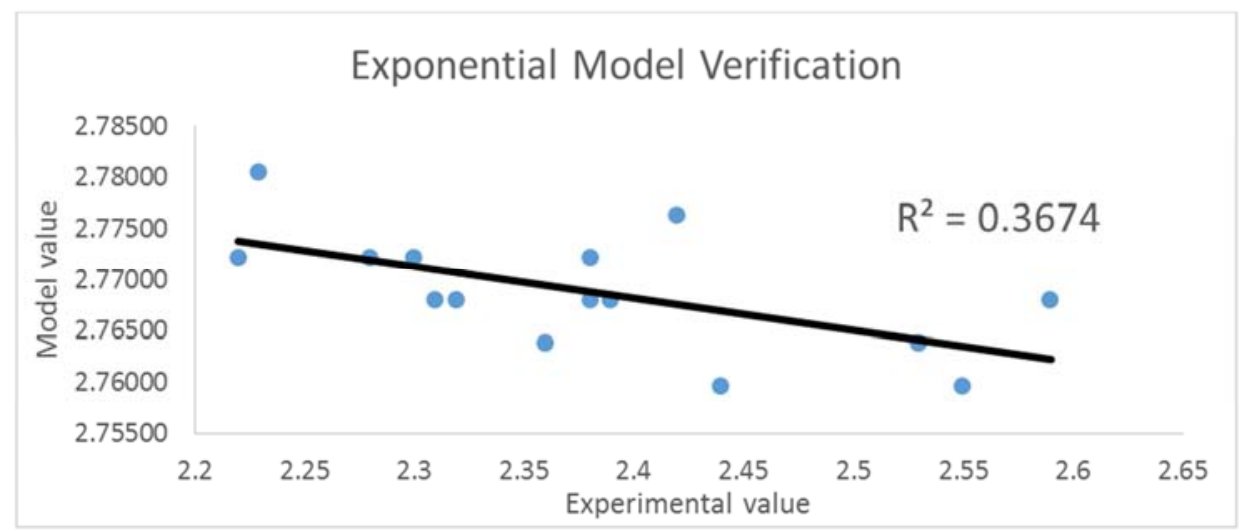

Figure 13. $R^{2}$ Analysis of Exponential Model. 


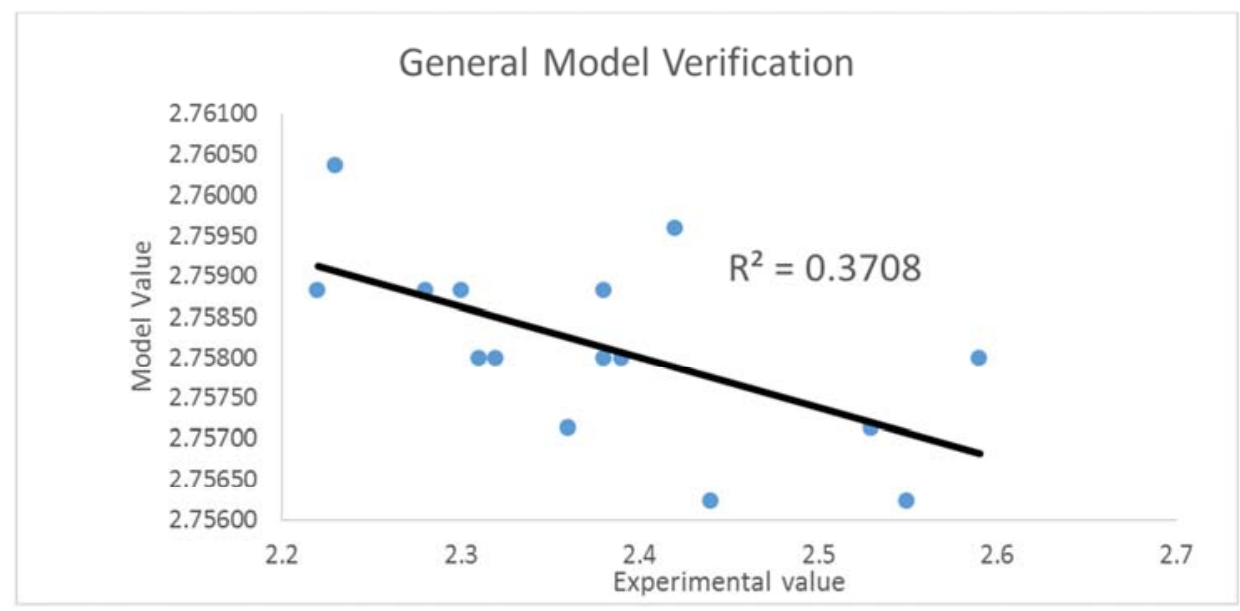

Figure 14. $R^{2}$ Analysis of general power Model.

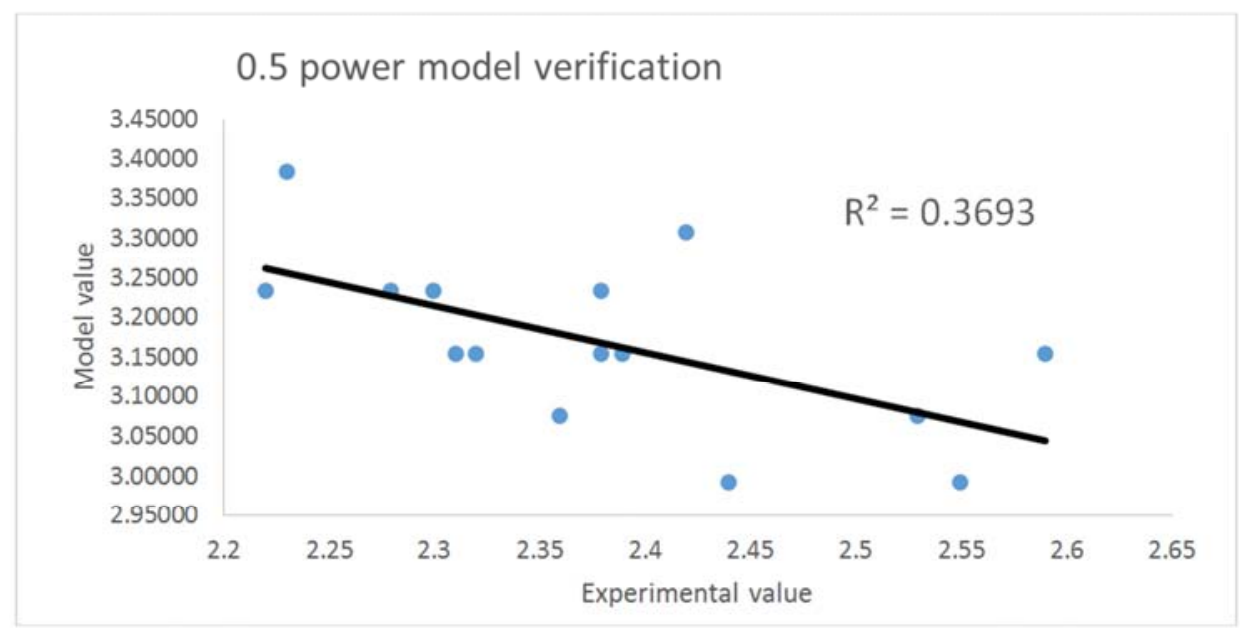

Figure 15. $R^{2}$ Analysis of 0.5 power Model.

The F- values from the different analysis were obtained with the aid of Tables 8 to 13 and Equations (14) and (15) as; $218.132,339.786,1278.130,382.448,9512.924$ and 1.073 for the linear, polynomial, logarithmic, exponential, general power and 0.5 power models in that order. For a significance difference of $5 \%$, the tabulated F- value for (15-1) degrees of freedom from the F- table is 2.483. All models except the 0.5 power model proved inadequate in relating the slump height and water absorption of PSA cement concrete as their Fcalculated values were well above the F- tabulated value. Thus, following results from F- statistics, the null hypothesis was accepted with regards the F-statistics of the 0.5 model analysis signifying that there is no significant difference between the model and experimental water absorption values whereas, the alternate hypothesis was accepted for all other models developed signifying a significant difference between the model and experimental values of water absorption of PSA cement concrete.

Results from the $\mathrm{R}^{2}$ analysis seemed to disagree with that from the F-statistics. The $\mathrm{R}^{2}$ values were obtained with the aid of Equation (16) and displayed in Figures 10 to 15 . These values were small and far short of 1 . This indicated that all models developed will predict values not too close to the experimental values. Although the models would predict values not too close to the actual values, they could be relied upon in relating these responses thereby giving an insight into how durable a PSA cement concrete could be given its slump value.

\section{Conclusions}

From the investigations of this study, the following conclusions can be made concerning investigating the relationship between workability and water absorption of PSA cement concrete:

a) The periwinkle shell ash is a "Class C" pozzolan and can be effectively used in partially replacing cement especially in its calcined state.

b) Models relating workability and water absorption of PSA cement concrete has been established. Any of these models can be adopted in predicting the water absorption of PSA cement concrete when the slump value is known.

c) With respect to the F-Statistics test, the 0.5 power relationship model proved adequate in predicting both responses of PSA cement concrete. The other 
relationship models were inadequate in predicting the responses.

d) From the $\mathrm{R}^{2}$ test conducted, the $\mathrm{R}^{2}$ values obtained for all the models developed were approximately 0.37 which is far short of 1 , signifying that a poor correlation between these responses of PSA cement concrete.

e) Although the 0.5 power model proved adequate from Fstatistics, little correlation exist between workability and water absorption of PSA cement concrete.

\section{Recommendations}

a) The aggregates used in this study were both uniformly graded. The use of well graded aggregates is hereby recommended for further study.

b) Relationship between other properties of PSA cement concrete should also be investigated.

c) In model development, adequacy tests (F-test, t- test, chi square, etc) and verification tests $\left(\mathrm{R}^{2}\right.$ test, MAPE test, etc) should be used in model validation. It is not satisfactory to rely on result from one alone as shown in this study.

\section{References}

[1] Nnochiri, E. S. and Aderinlewo, O. O. (2016). Lateritic Soil Stabilized with Periwinkle Shell Ash in Road Construction. Int. Journal of Advanced Engineering, Management and Science (IJAEMS). Vol 2 (5). ISSN 2454-1311.

[2] Dahunsi, B. I. and Bamisaye J. A. (2015). Use of Periwinkle Shell Ash (PSA) As Partial Replacement for Cement in Concrete.

[3] Ubong, D. O., and Godwin, E. A. (2017). Assessment of Physico-Chemical Properties of Periwinkle Shell Ash as Partial Replacement for Cement in Concrete. International Journal of Scientific Engineering and Science. Vol. 1 (7) pp 33-36.

[4] Olutoge, F. A., Okeyinka, O. M and Olaniyan, O. S. (2012). Assessment of the suitability of Periwinkle Shell Ash as Partial Replacement for Ordinary Portland Cement (OPC) in concrete. IJRR.
[5] Ochepo, J. and Salahudeen, A. B. (2015) "Durability Of Cement Concrete Partially Replaced With Baggase Ash Subjected To Aggressive Environments". Books of Proceedings, International Conference for Sustainable Development (ICSD) in Africa in the $21^{\text {st }}$ Century. Post Graduate School, Ladoke Akintola University of Technology, Ogbomosho, Nigeria.

[6] Rajput R. K. (2006). Engineering Material (including construction Materials). New Delhi. S. Chand \& Co. Ltd.

[7] Online (2017). Composition of Glass. www. cmog. org/article/chemistry of glass. Retrieved 10th August, 2017.

[8] Zhang S. P. and Zong L. (2014). Evaluation of Relationship between Water Absorption and Durability of Concrete Materials. Advances in Material Science and Engineering. Vol 3 (4) pp 1-8.

[9] ASTM C140 (2001). Water Absorption Criteria of Cement Concrete. American Society for Testing and Materials, West Coshohocken, USA. ASTM C140.

[10] BS 12. (1996). Standard Specification for Portland Cement. British Standard Institution, BS 12.

[11] IS - 383 (1970). Specification for Coarse and Fine Aggregate. Indian specification: IS-383.

[12] IS - 2386 (1963). Methods of Test of Aggregates for Concrete. Part 4: Mechanical properties. IS-2386.

[13] Scheffe, H. (1958). "Experiments with Mixtures". Royal Statistical Society Journal”. Series B. 20, 344-360.

[14] BS 1881: Part 102 (1983). Standard Specification for Determination of Slump (BS 1881: Part 102). London, British Standard Institution.

[15] ASTM D3171 (2008). Standard Test Method for Water Absorption of Cement Concrete. American Society for Testing and Materials, West Coshohocken, USA. ASTM D3171.

[16] BS EN 197 - 1- (2009). Cement Composition, Specification and Conformity Criteria for Common cements. London, British Standard Institution.

[17] ASTM C618 (2008). Classification of Pozzolanic Materias. American Society for Testing and Materials, West Coshohocken, USA. ASTM C618. 